\title{
GREAT CIVILIZATIONS POPULATION INCREASE/DECREASE FACTOR
}

\author{
Andi Mihail BĂNCILĂ \\ bancila.andi@gmail.com \\ MILITARY TECHNICAL ACADEMY, BUCHAREST, ROMANIA
}

\begin{abstract}
Demographic changes that currently affect the planet are not fully new, they have continued throughout history, managing to influence geographical areas and making changes to individuals' lifestyle. The phenomenon of international migration has become a topical issue in 2015 with the increasing number of asylum seekers on the territory of the European Union. This special event raised new questions about the socio-economic evolution of the European continent, with problems being signaled both from the perspective of newcomers and permanent residents of this space. The main task that the political authorities of the member states of the community block have over the next years is to identify a solution through which to achieve appropriate and long-term integration of newcomers, many of them belonging to different cultures of the majority population.
\end{abstract}

\section{KEYWORDS:}

Population, migration, demography, starvation, growth rate

\section{Introduction}

If we are to look back retrospectively through out History, one notices that, powerful ideas which made waves throughout XIX and XX centuries, which created pseudoscience to justify them, have become, in time, examples to be avoided by future generations. These concepts which had to sustain the superiority of some groups over some other, based on principles lacking scientific fact, such as eugenics or the "human race" purity principle, remained in the collective memory as some aberrations of foretime. Unfortunately for our contemporary society, concepts of segregation started reappearing, this time justified by religion. This type of approach is far from new, as it dates back to the Dark
Era, and brought to actuality on the foundation of an important faulty modern society.

\section{The population evolution from ancient times to modern times \\ The term "race" is wrongfully used} by most people, being interpreted as an element of separation of the human individuals in terms of skin color, cultural and ethnical aspects, geographical positioning or aspects regarding language or religion. From a scientific point of view, man is the only species of the animal kingdom represented by one race only, Homo Sapiens (Kaplan \& Winther, 2013, 40).

The common ancestor of the modern man (Homo Sapiens), and his kin, the 
Neanderthal, left the African continent, his genesis location, approximately 1.9 million years ago. For over 1.2 million years, the anatomic changes caused by the environment are too inconsistent to be studied, but starting with the year 700.000 B.C. the Homo Erectus evolves distinctly, setting the base of the two most common known human species. Around the year 350.000 in the same period, the Neanderthal inhabited Middle East and all of Europe, whilst Homo Sapiens evolves in much more favorable climate conditions, on the African continent. By 100.000 of the same time period, modern men leave Africa to start their big migration worldwide (Keys, 2015). It is estimated that modern men finalized their migration about 14.500 years ago, when they arrived on the territory of today's Chile (Wolman, 2008). For a short period of time, the two species evolved together, with evidence sustaining DNA crossing between the two. Geneticists confirm today that European DNA has traces of the former inhabitants of the continent. This fact allows them to resist colder environments, compared to those that never left "the Black Continent".

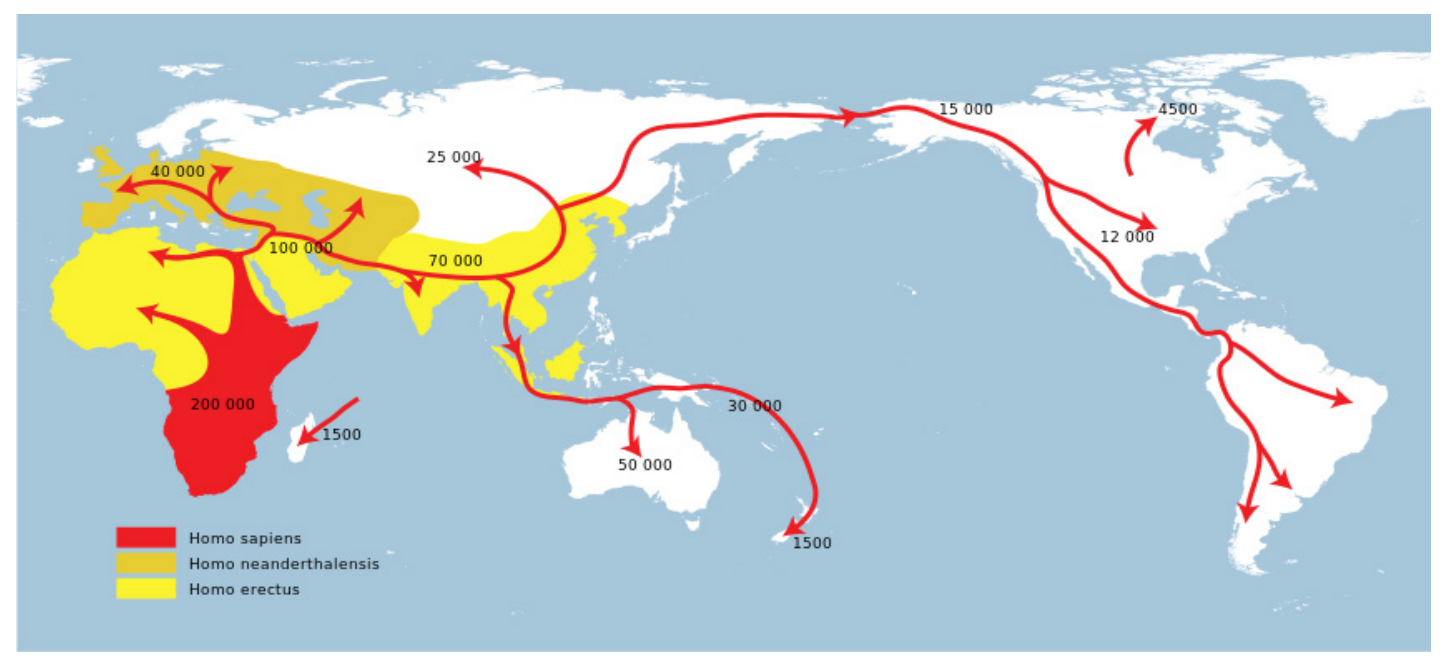

Figure no. 1 The migration of the human race (http://www.scientia.ro)

The competition for resources, especially food, has been fierce both in between the two species and also inside the same groups. As a result of an unsustainable food procuring system, the small groups of Neanderthals consisting most probably of 10-12 men encountered great difficulties in protecting their own habitat. The species considered to be more evolved, i.e. homo sapiens, evolved in larger groups of individuals, capable of hunting animals of greater size, ensuring enough nourishment even in unfavorable climate changes. This theory is being supported by Dr. Laluenza Fox (2011) within the Biology Institute of Barcelona, who proved the brittleness of small groups of Neanderthals. In 1994, in the caves of El Sidron, Spain, bones of a small human community of 51.000 years old Neanderthals had been discovered. After the conducted study in the Institute's labs, it was concluded that the cause of death has been a violent one. Most probably the group, composed of 3 children of 9 years, 3 teenagers and 6 adults, was sacrificed by another neighboring group for food. Climate change is by far unfavorable for this species, being unable to adapt the new environment. The most powerful part of the "Wurm" glaciations happening 25.000 years ago, created a penury of food, which resulted in the extinction of the Neanderthals. 
Following these events, one can see how closely related man is with the available resources, especially food. These factors allowed excess nourishment to be developed in favorable areas, seeding the first great human civilizations. Demographical research experts within the Population Division of The United Nations Organization have arrived at the conclusion that these factors strongly influenced the demographic growth, especially as a result of new land working technology. These new means facilitated the growth factor, increasing agricultural productivity and reducing the human dependency over nature and setting the foundation of the first demographic revolution of the planet. UN specialists estimated that at the end of the Paleolithic era, at the Nile valley area, the number of inhabitants exceeded 20.000, considering the world population was about 5 million (United Nations, 1978).

According to the geographical distribution criteria, the skin color or other cultural elements, the human race has a few subdivisions: European (Caucasian),
Mongoloid, and Australo-Negroid. The last has two more subdivisions, according to geographical positioning: Negroid found in Sub-Saharan Africa, and the second, Australoid, spread in Australia, New Guinea and most of Micronesia.

The numeric population growth has a sinusoidal evolution with many variations. The main cause is represented by the slow and faulty evolution of the nourishment system, often incapable of ensuring enough calories for a certain population. As a consequence, the malnourished and hygiene deprived individuals were most exposed to plagues. The most important event of modern history is represented by the Bubonic Plague (also known as the "Black Death") between 1347-1351. During this time it is estimated that $30-60 \%$ of the population of Europe (Theilmann and Frances, 2007) had died. There are significant cities in which the death rate reached a staggering $80 \%$. The population loss was later recovered as a result of increasing birth rate, in approximately 150 years.

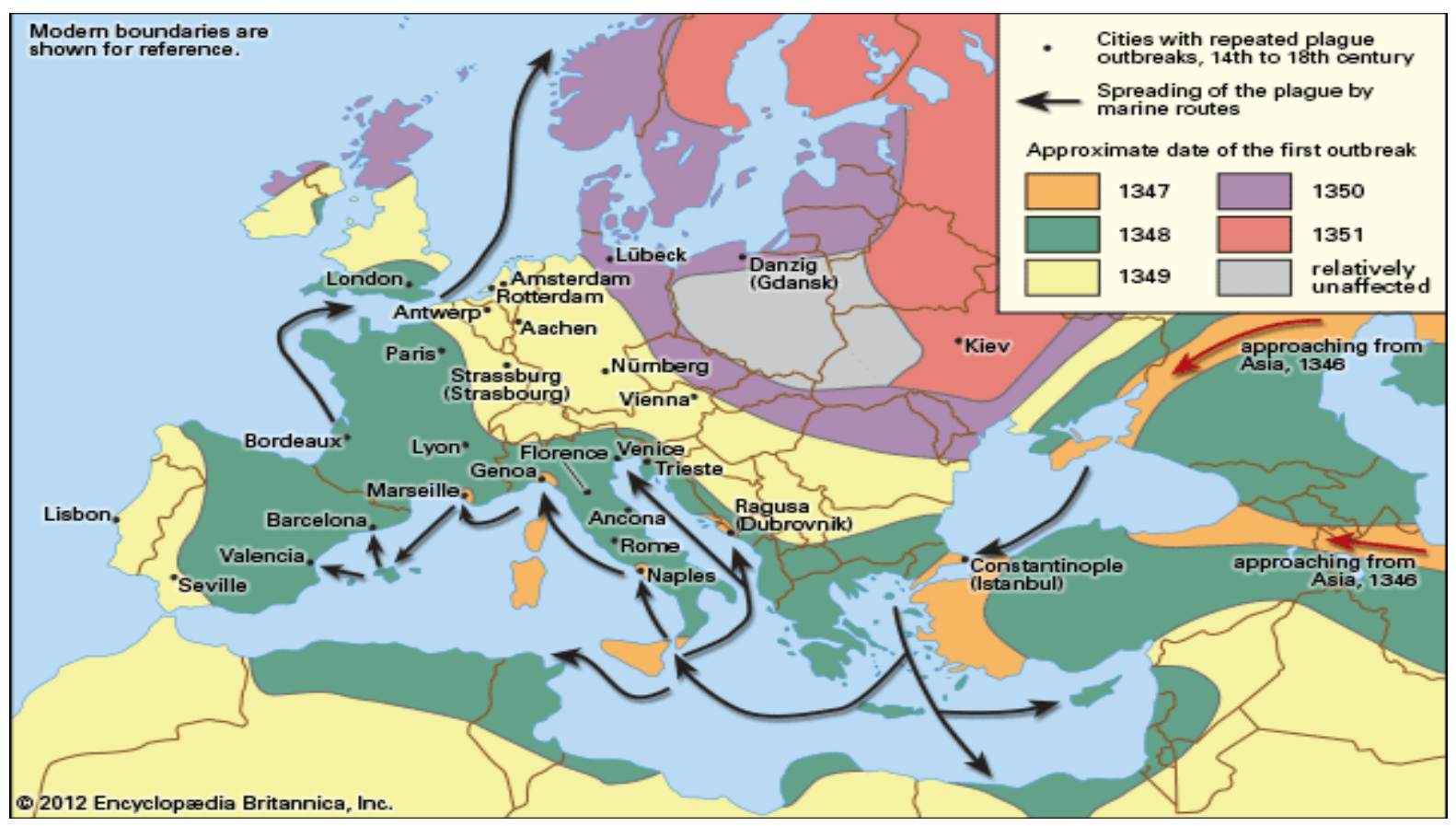

Figure no. 2 Bubonic Plague transmission in Europe, years 1347-1351 (Britannica Kids, 2016) 
The intoduction of potato and corn on the European table seemed to have solved the food problem, at least for a time being. Aside from potato and corn, brought to Europe in the "Columbian Exchange (Nunn and Qiam, 2010)", the explorers also enriched the Europeans's menu with tomato, pumpkin, beans, pepper, sunflower, and last, sugar (sugar cane, the plant from which the high calory product was extracted, couldn't survive in Europe, so it could be only brought as sugar). These plants, with a high prodictivity and more calories, compared to the cereals already used by europeans, contributed decisively to the health improvement and population growth of the europeans. Economists who analyzed the effects of these plants regarding the european food menu, concluded that a single acre of cultivated land with sugar canes produced a caloric equivalent of 12 acres of wheat (Niall, 2011, 54). In order to study the effects generated by this caloric improvement, Ferguson Niall,a wellknown British historian, compared the average height of a XVIII century Britishsoldier, with a japanese one from the same time period. This comparison was more relevant because, as the Europeans were beginning to trade globally, the japanese started isolating themselves from the rest. The superior caloric intake determined a 13 centimeter difference between the British and the Japanese (Niall, 2011, 55), the former being taller.

These facts considered, the european growth rate entered a new phase, in which the growth rate was superior to any other period. Up to that moment, sickness, war and malnutrition determined a reduced demographic dynamics, but even if the death rate mantained at the same level, the caloric intake favorised the rapid growth of newborn. To undestand the effects caused by this phenomenon, we need to observe the demographic estimations from the Roman Empire's fall (when demographic evidences were held) to the beginning of the industrial age. At the final moment of the migration era it was estimated that there were about 40 milion inhabitants in Europe, a number with little variation for more than 1000 years. The first estimation which states a doubled number of inhabitants is dated at the end of the XIV century. Starting from then, as a result of the positive effects the new plants provided, an unprecedented demographical growth was observed. In just 250 years, the number of registered people almost doubled compared to the recordings over the millenia, from the fall of the Roman Empire, reaching a 60 milion growth in population, totalling 140 million (Rotariu, 2009, 198).

The visible growth of the number of inhabitants was signaled even by the contemporary. In 1776 Adam Smith was mentioning the link between the avalible food resources in a certain space and the demographical evolution: "Any animal species thrives according to the means of subsistence and there is no species to be able to reproduce more than this one". A few decades later, his theory was contested by the more skeptical Malthnus, who argued: "nourishment is mandatory to the human survival and the population growth potential exceeds the soil's ability to produce means of subsistence for the human (Livi-Bacci, 2003, 51-52)".

One of the main causes for which Europe was vulnerable to sudden shortages of food was the lack of some important agricultural projects, capable of mentaining (during droughts) and, if needed, increase agricultural productivity. Unlike Asia, where farmers were forced to participate in building some important projects (canals, roads, terraforming) (Jones, 2003, 10), in Europe, the increase of food provisions was insured by obtaining new farming land by deforestation or draining wild lands. Starting with the XVIIth century, the situation changes. The Europeans, constrained by the demographic pressure, had to perfect methods in order to protect the agricultural areas (the swampy soil in 
the Netherlands, who used important dam systems). This way, they managed the performance of avoiding floods, which were a threat to any agricultural surface (Jones, 2003, 28).

\section{Current Demographic Evolution}

The demographic growth increased at the beginning of the XIXth century, when it is estimated that humankind achieved the most important step of its history, exceeding one billion inhabitants. Later, the number of people living on planet Earth increased in a rate that no one would have anticipated a century before. The second billion inhabitants was reached in 1927, the third was estimated to have been reached in 1960, and in the next 40 years the global population doubled again. According to the Institute of Statistics of the UN, in 2011 the population worldwide reached a staggering 7 billion and it is estimated that by the time half a century passes, the number will reach 9 billion. This perspective is sustained by the fact that at this moment there is a global level of about 1,8 billion fertile women, fact that contributes to the growth with about 80 million people each year (Kunnzing, 2011, 37). Demography specialists calculated that every day, the demographic plus reaches about 250.000 new citizens (worldometers.com, 2016).

This abrupt growth in population succeeded in bringing back the old preoccupation regarding the number of people and the available resources. This interest has been expressed by politicians and scientists throughout history. Every time it was thought that the number of citizens exceeded the sustaining resources, an big-enough number of people suggested implementing strict methods of demographic control. A lot of them thought they could diminish the number by armed conflict, which proved to be undocumented. The most bloody war in the history of mankind, World War II, which took place between1939-1945, regrettably succeeded in reducing the global population with approximately 50 (http://warchronicle.com) to 70 million (secondworldwarhistory.com, 2017) people. If we are to take into account the actual growth rate, all the loss can be recovered in less than one year; this fact proves that the war is useless as a means of demographic control. If the use of nuclear weapons is taken into account in a global scale conflict, we would risk total annihilation of humans.

In recent history, there is another model of family planning through which was intended to avoid a food crisis. This method proposed the introduction of law regulations in order to control births. "The only child" policy, adopted in China starting 18th of September 1980 (Sonawane, 2016) avoided the birth of over 400 million children (Whyte, Feng \& Cai, 2015, 146). The long term costs of such project are disastrous, as today China feels the growth of costs in manpower and implicitly the decrease of her economical competitivity for some industries. The method through which the Chinese government obtained the sudden diminish in birth rate is a very strict one, applied harshly and which, over time, created suffering and even unbalance regarding the genders, 40 millions more males than females presently. 


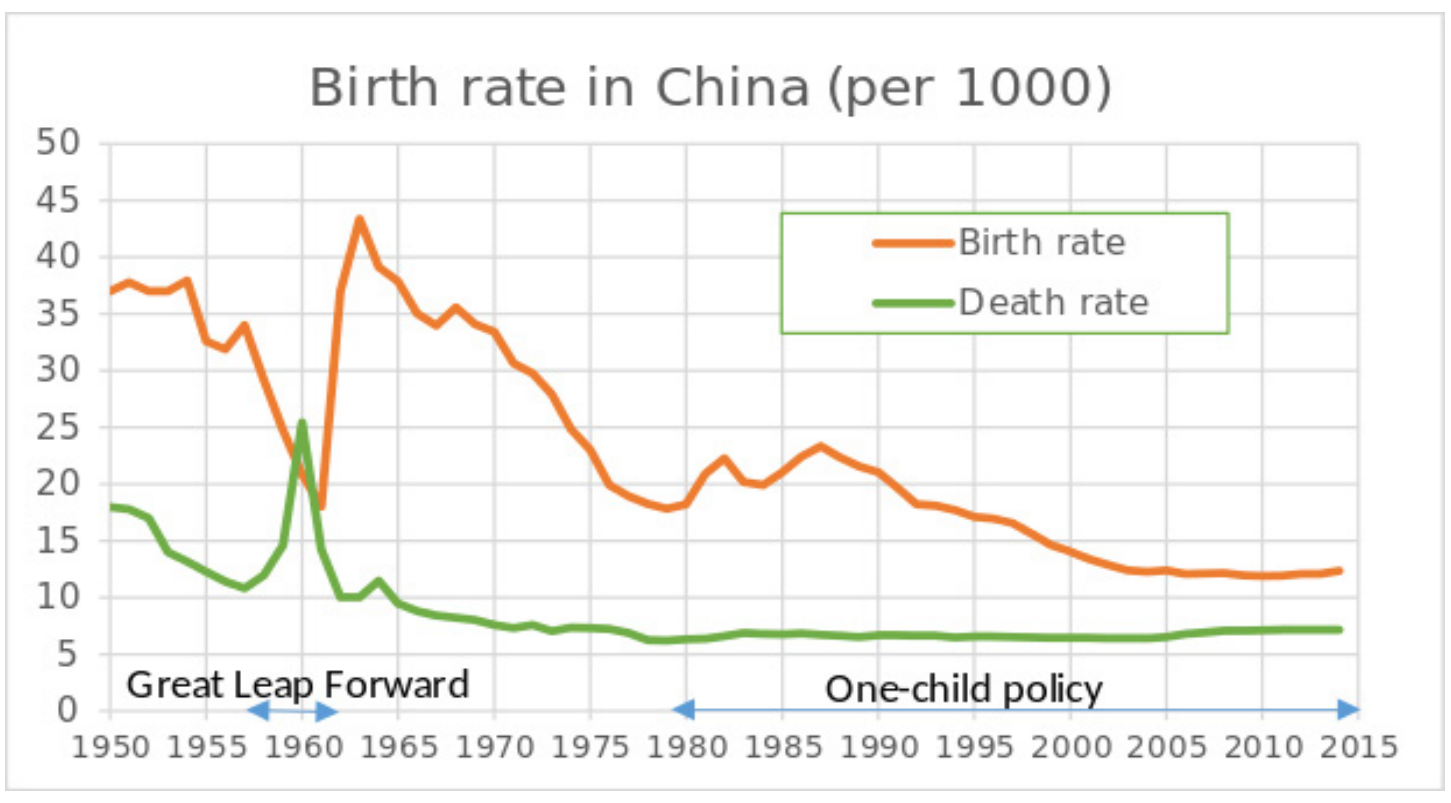

Figure no. 3 The evolution of growth rate in China, starting the second half of the XXth century (http://www.china-profile.com)

No country in Africa is viable for such a policy. The communist Chinese state was and still is a super centralized state in which the government has the ability to implement any type of policy, even by force. The vast majority of the African states, which record abrupt growths in population number, are weak states in which the government doesn't have the ability to control whe whole country. Even more, the costs of applying such policy are great. The great challenge China will have to handle in the next 20-30 years is the accelerated aging of the population, fact that will generate huge social costs. It is estimated that by 2050 , there will be over 440 million inhabitants living in China, with the age over 60 (Phillips, 2015). Seeing this problem, starting 1st of January 2016 (Evans, 2016), the Chinese government allowed couples to have a second child. This fact proves that such a political constraint is faulty on the long term.

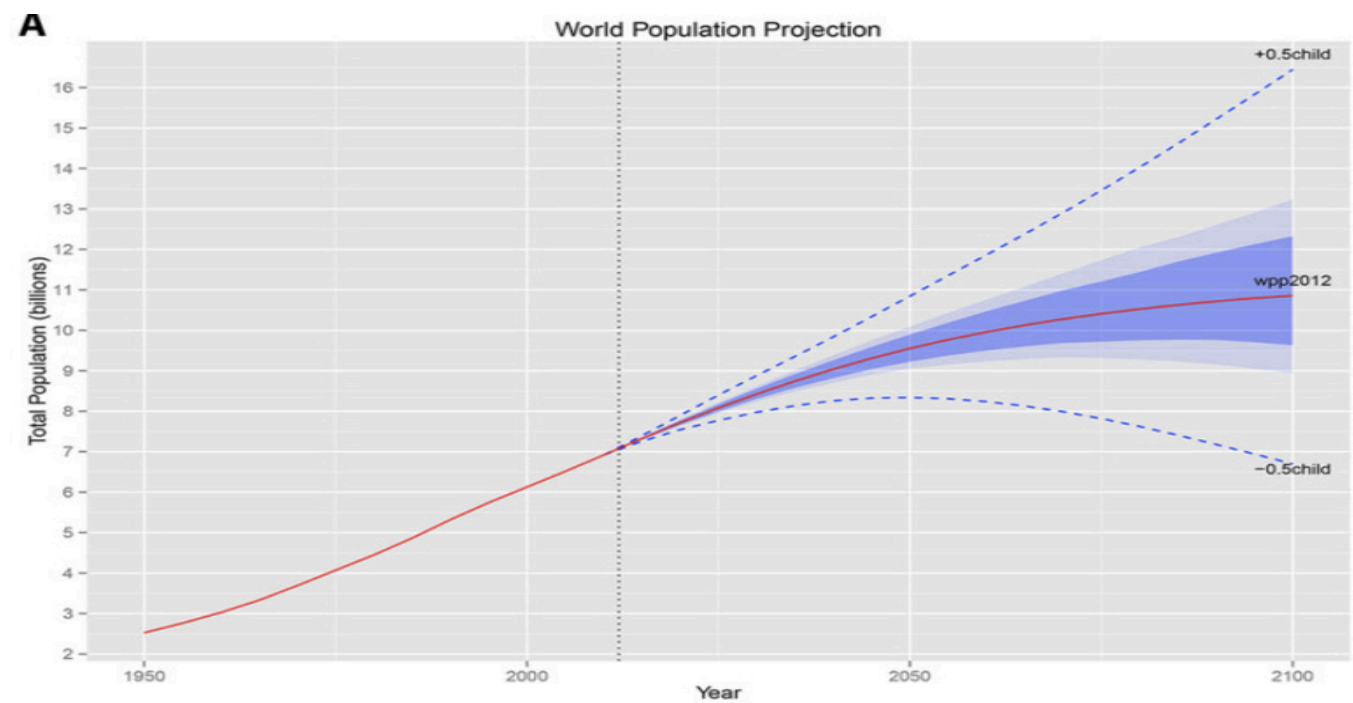

Figure no. 4 The estimated global population growth by 2100 (http://scinews.ro) 
Even if Europe, North America, Australia and an important part of Asia constantly registers negative demographics, decreasing their population over the years, the increase in life expectancy also increased the global population growth. This fact is very visible especially in poorly developed spaces, where the population is also undeveloped. The continent which has the fastest population growth rate is Africa. According to actual growth statistics, published by Wendy Baldwin, president of the Population Evidence Bureau of Washington, it is estimated that this continent will practicly double in population in a very short time. Approximately 1,1 billion people inhabit Africa presently, and it is about to rise to 2.4 billion by 2050 (Pflanz, 2013). Following this growth statistics it can be noted that the population doubles in about 30-40 years. If the population growth factor remains constant on the African continent, the population doubles in a smaller interval. At this time, every woman on this continent has a rate of 5.2 children, tipping 7.1 children for women in Niger (Institut National de la Statistique, 2012), one of the poorest countries in Subsaharian Africa.

\section{Conclusion}

A great number of people did not necessary mean joy. For many states, this blessing turned into a great burden because of lack of space or technology to insure food. At the beginning of the XXIth century, the global population was split accordingly: Asia $59.1 \%$, North \& South America $13.9 \%$, Africa $13.8 \%$, Europe $12.7 \%$, Australia \& Oceania $0.5 \%$ (Săvoiu, 2006, 100). Unfortunately a great numbe of inhabitants are living in areas lacking resources for sustenance. The most dramatic situation is found around Subsaharian Africa, which at this moment registers the highest growth rate and therewith the fastest soil feritlity depletion rate. Despite a great number of people suffers from starvation and estimations of various institutes of statistics anticipate that their numbers are increasing. A great part of the food is used to cover other needs. According to economical statistics at the global scale, only $55 \%$ of the produced food is used. One of the sectors to which a great part of the produced cereals are redistributed is the biofuels department, aproximately $36 \%$ of the whole (Foley, $2014,45)$. This fact raises a lot of eyebrows regarding the management of this precious resource and underlines that the global food strategy should be remastered.

\section{REFERENCES}

Britannica Kids. (2016). The reach of the Black Death in Europe from 1347 to 1351 can be seen as it spreads year by year, available at: http://kids.britannica.com/comptons/art166726/The-reach-of-the-Black-Death-in-Europe-from-1347, accessed at 12.05.2016.

Evans, S. (2016). China's one-child policy ends, available at: http://www.bbc.com/ news/world-asia-china-35208488, accessed at 02.01.2017.

Foley, J. (2014), A five step plan to feed the world, National Geographic, 45.

Institut National de Statistique. (2012). Annuaire statistique 2007-2011, available at: http://www.stat-niger.org/statistique/file/Annuaires Statistiques/AS20072011STRUCTUREPOPULATION.pdf, accessed at 15.05.2017.

Jones, E. (2003). The european miracle. Environments, economies and geopolitics in the history of Europe and Asia, New York: Cambridge University Press, 10.

Kaplan, J. M. \& Winther, R. G. (2013). Prisoners of abstraction? The theory and measure of genetic variation, and the very concept of "Race", Biological theory, No. 7/2013, 40. 
Keys, D. (2015). Scientist reveal what our long-lost virtual ancestor looked like before evolutionary split 700.000 years ago, The Independent, available at: http://www.independent. co.uk/news/science/scientists-reveal-what-our-long-lost-virtual-ancestor-looked-like-beforeevolutionary-split-700000-a6777736.html, accessed at 31.01.2016.

Kunnzing, R. (2011). Omenirea, 7 miliarde, National Geographic, No. 93, 37.

Lalueza-Fox C. (coord.) (2011). Genetic evidence for patrilocal mating behavior among neandertal groups, Proceedings of the National Academy of Sciences of the United States of America, Vol. 108, No. 1, available at: http://www.pnas.org/content/108/1/250.full?

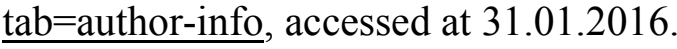

Livi Bacci, M. (2003). Populația în istoria Europei, Iași: Polirom, 51-52.

National Bureau of Statistics of China. (2014). China statistical yearbook 2014, chapter 2 Population, available at: http://www.china-profile.com/data/fig p 10.htm.

Niall, F. (2011), Civilizația.Vestul și restul, Iași: Polirom, 54.

Nunn, N. \& Qian, N. (2010). The columbian exchange: A history of disease, food, and ideas, The journal of economic perspectives, Vol. 24, No. 2, Spring, 167.

Pflanz, M. (2013). Africa's population to double to 2.4 billion by 2050, available at: http://www.telegraph.co.uk/news/worldnews/africaandindianocean/10305000/Africaspopulation-to-double-to-2.4-billion-by-2050.html, accessed at 24.09.2016.

Phillips, T. (2015). China ends one-child policy after 35 years, available at: https://www.theguardian.com/world/2015/oct/29/china-abandons-one-child-policy, accessed at 02.01 .2017 .

Rotariu, T. (2009). Demografie și sociologia populației, Iași: Polirom, 198.

Săvoiu, Gh. (2006). Numărul populației, o sinteză statistică și economică a evoluției alternative către explozie sau implozie demografică, Economie teoretică și aplicată, No. 8 (503), 100.

Scinews.ro. (2014). Populația lumii ar putea ajunge la 11 miliarde în 2100, available at: http://scinews.ro/populatia-lumii/, accessed at 02.01.2017.

Secondworldwarhistory.com. (2017). World War 2 Statistics, available at: http://www.secondworldwarhistory.com/world-war-2-statistics.asp, accessed at 02.01.2017.

Sonawane, V. (2016). China's two-child policy takes effect, but couples apprehensive amid economic slowdown, available at: http://www.ibtimes.com/chinas-two-child-policytakes-effect-couples-apprehensive-amid-economic-slowdown-2246434, accessed at 02.01.2017.

Theilmann, J. \& Frances, C. (2007). A plague of plagues: The problem of plague diagnosis in medieval england, The Journal of interdisciplinary history, Vol. 37, No. 3, Winter, 376.

United Nations. (1978). Causes et consequences de l'evolution demographique, New York: United Nations, 13.

Whyte, M. K., Feng, W. \& Cai, Y. (2015). Challenging myths about China's one child policy, The China journal, No. 74.

Wolman, D. (2008). Fossil feces is earliest evidence of N. America Humans, available at: http://news.nationalgeographic.com/news/2008/04/080403-first-americans.html, accessed at 06.02 .2017 .

Worldometers.com. (2016). Statisticile lumii $\hat{\imath}$ timp real, available at: http://www.worldometers.info/ro/, accessed at 30.12.2016.

www. warchronicle.com/numbers/WWII/deaths.htm, accessed at 02.01.2017. 